\title{
Contribution of Ammonia and Defoamers to Lower Flammability Limit in SRS High Level Waste Tanks
}

\author{
R. F. Swingle, II and T. L. White \\ Westinghouse Savannah River Company \\ Savannah River Site \\ Aiken, SC 29808
}

This document was prepared in conjunction with work accomplished under Contract No. DE-AC09-96SR18500 with the U. S. Department of Energy.

DISCLAIMER

\begin{abstract}
This report was prepared as an account of work sponsored by an agency of the United States Government. Neither the United States Government nor any agency thereof, nor any of their employees, makes any warranty, express or implied, or assumes any legal liability or responsibility for the accuracy, completeness, or usefulness of any information, apparatus, product or process disclosed, or represents that its use would not infringe privately owned rights. Reference herein to any specific commercial product, process or service by trade name, trademark, manufacturer, or otherwise does not necessarily constitute or imply its endorsement, recommendation, or favoring by the United States Government or any agency thereof. The views and opinions of authors expressed herein do not necessarily state or reflect those of the United States Government or any agency thereof.
\end{abstract}

This report has been reproduced directly from the best available copy.

Available to DOE and DOE Contractors from the Office of Scientific and Technical Information, P. O. Box 62 Oak Ridge, TN 37831; prices available from (423) 5768401.

Available to the public from the National Technical Information Service, U.S. Department of Commerce, 5285 Port Royal Road, Springfield, VA 22161.

\section{Summary}

The evaluation of ammonia and siloxane defoamers in the Tank Farm Waste Acceptance Criteria ${ }^{4,5}$ has been rechecked. This evaluation has been found acceptable with the correction of an error that was discovered in the original calculation of allowable liquid phase ammonia concentration. ${ }^{1}$ A corrected ammonia [concentration of $0.84 \mathrm{wt} \%$ has been calculated to give a vapor pressure of 15 vol\% over $6.2 \mathrm{M}$ $\mathrm{Na}^{+}, 1.7 \mathrm{M} \mathrm{OH}^{-}$salt solution at $70{ }^{\circ} \mathrm{C}$. This is further reduced to $0.27 \mathrm{vol} \%$ for a $12 \mathrm{M} \mathrm{Na}^{+}, 2.3 \mathrm{M} \mathrm{OH}^{-}$salt solution at $70^{\circ} \mathrm{C}$. The original calculation of the salt solution ammonia concentration that would be in equilibrium with an ammonia concentration in the vapor phase at its LFL (14.8 vol\%) was $1.27 \mathrm{wt} \%$ for 6.2 $\mathrm{M} \mathrm{Na}^{+}, 1.7 \mathrm{M} \mathrm{OH}^{-}$salt solution at $70^{\circ} \mathrm{C}$. The ammonia concentration in the liquid that gives a vapor phase concentration of $14.8 \mathrm{vol} \%$ is reduced by increasing salt concentration (especially $\mathrm{OH}^{-}$) and temperature.

As a result of the changes provided herein, it is recommended that the allowable ammonia concentration be adjusted and that it be tied to limits on sodium and free hydroxide concentration $\left(6.2 \mathrm{M} \mathrm{Na}^{+}\right.$and $1.7 \mathrm{M} \mathrm{OH}^{-}$ or $12.6 \mathrm{M} \mathrm{Na}^{+}$and $2.3 \mathrm{M} \mathrm{OH}^{-}$, depending on the ammonia limit used), to assure the validity of the limit on ammonia concentration. Ammonia limits may vary depending on sodium and hydroxide concentrations and the temperature.

\section{Introduction}


The High Level Waste Tank Farms store and process high-level liquid wastes from a number of sources including F- and H-Canyon, Receiving Basin for Offsite Fuels (RBOF), the 299-H Decontamination Facility and the Defense Waste Processing Facility (DWPF). These wastes are made alkaline prior to transfer to the Tank Farm and are subject to acceptance based on their composition. These wastes may contain minor concentrations of organic and other potentially flammable compounds. The Authorization Basis for the Tank Farms identifies several controls to prevent unwarranted, adverse chemical reactions. However, current analysis of the accident scenarios does not evaluate the impact of the presence of organic compounds. A Potential Inadequacy in the Safety Analysis (PISA) has been declared regarding the issue of organic compounds in the waste. ${ }^{2}$ Processing vessels of concern include the pump tanks (PT), waste tanks, (WT), and evaporators. Ammonia and defoamers were previously evaluated, and it was concluded that defoamers were not a problem and that ammonia was sufficiently controlled by current means. ${ }^{3,4}$ However, additional studies were recommended. This report documents further analysis of the flammability aspects of ammonia and siloxane defoamers.

\section{Discussion}

\section{Allowable Ammonia Concentration}

M. E. Jamison, concluded the following about ammonia receipts to the Tank Farm. ${ }^{4}$

Historically, the $\mathrm{F}$ and $\mathrm{H}$ canyons have sent bulk waste transfers containing ammonia from performing Process Vessel Vent (PVV) flushes and from reactor assembly dissolving. In 1976 the canyons changed their processing flowsheet to reduce the amount of ammonia generated by destroying hydrazine and sulfamate with nitrite. This change resulted in a 94\% reduction in the ammonia sent to the tank farms. Recent PVV flushes sent to the tank farm have been safely received by limiting the ammonia to $10 \%$ of the LFL under equilibrium conditions (i.e., 0.127 wt.\% ammonia at $70^{\circ} \mathrm{C}$ ).

The DWPF recycle water, during sludge only operations, sends trace concentrations of ammonia to the tank farm. However, after coupled operations commence [should a tetraphenylborate process be used] the ammonia concentration in the DWPF recycle will increase. The DWPF WCP (Waste Compliance Plan) for couple operations will address the $10 \%$ CLFL (composite lower flammability limit) ammonia requirement prior to receipt.

\subsubsection{Required Controls to Safely Receive Ammonia}

To ensure a CLFL is not reached, influent transfers must be limited to $<25 \%$ of CLFL under liquid-vapor equilibrium. A more restrictive 10\% LFL requirement will be implemented in the Tank Farm Waste Acceptance Criteria (WAC) to reduce the industrial hygiene risk and to allow other flammable constituents to be present while maintaining a CLFL below 25\%.

The Tank Farm WAC ${ }^{5}$ has been revised to control ammonia in transfers to the Tank farm as recommended. ${ }^{4}$

Control of the ammonia concentration so that it will only contribute 10\% of CLFL in organic tanks and $<=5 \%$ of CLFL in non-organic tanks should assure that ammonia does not become an LFL concern. In a caustic environment, ammonia will exist largely in the free ammonia form (as opposed to the ammonium form) and will tend to vaporize and be flushed from waste tanks by the ventilation system. Therefore with these controls in place, the maximum amount of ammonia that would be expected is right after a transfer that is high in ammonia. Since there are controls on the initial concentration of ammonia (and ammonium) 
coming into the Tank Farm and since in most cases transfers in are likely to be considerably diluted by existing material, ammonia should not be a flammability concern. Additionally, ammonia has relatively high vapor pressure under tank farm conditions, as well as a high LFL (15\%). Since the LFL is high, the partial pressure of ammonia in the vapor space can be fairly high $(\sim 1.5 \%)$ with out causing any concern. This allows ammonia to be removed from the tank fairly rapidly with the vapor space turnover.

Reference 1 provided the basis for ammonia concentration limits given in the WAC. An error was found in that report, and the corrected information is provided below. Additionally, the information provided in Reference 1 was generated for a salt solution that is $6.2 \mathrm{M}^{\text {in Na}}{ }^{+}$and $1.7 \mathrm{M}^{\text {in } \mathrm{OH}^{-}}$. This information is not conservative for salt solutions that contain higher concentrations. Since the original report ${ }^{6}$ from which this

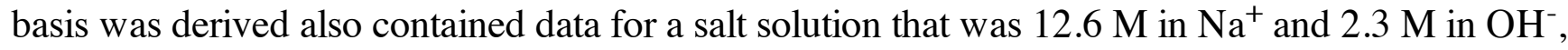
ammonia concentration information for that salt solution is provided in this report also.

Equation 1 gives the expression for the Henry's Law derived from data obtained with $6.2 \mathrm{M} \mathrm{Na}^{+}, 1.7 \mathrm{M}$ $\mathrm{OH}^{-}$salt solution. Equation 2 gives the Henry's Law expression for a $12.6 \mathrm{M} \mathrm{Na}^{+}, 2.3 \mathrm{M} \mathrm{OH}^{-}$salt solution. ${ }^{6}$

$$
\begin{aligned}
& \ln K_{s}=-7.357+3330.1 *(1 / T)-0.002139 * T \\
& \ln K_{r^{\prime}}=-7.577+2571.3 *(1 / T)+0.003076 * T
\end{aligned}
$$

In both equations the $K_{H}$ represents the Henry's Law Constant and $T$ represents the system temperature in Kelvin. Equation (1) is conservative for use in the pump tanks, but may not be acceptable for many waste tanks. Equation (2) extends the number of waste tanks for which conservative data are available. These equations were used to calculate ammonia partial pressures for a range of liquid phase ammonia concentrations. Tables 1 and 2 give data for $6.2 \mathrm{M} \mathrm{Na}^{+}, 1.7 \mathrm{M} \mathrm{OH}^{-}$salt solution and $12.6 \mathrm{M}^{2} \mathrm{Na}^{+}$and 2.3 $\mathrm{M}$ in $\mathrm{OH}$ salt solution respectively. Figures 1 and 2 provide plots of the ammonia partial pressures versus temperature for various ammonia concentrations in the two salt solutions tested.

Table 1. Calculated Partial Pressures of Ammonia in Equilibrium with 6.2 $\mathrm{M} \mathrm{Na}^{+}, 1.7 \mathrm{M} \mathrm{OH}^{-}$

\begin{tabular}{|c|c|c|c|c|c|c|}
\hline & \multicolumn{6}{|c|}{ Liquid Phase Ammonia Concentrations } \\
\hline \multicolumn{2}{|c|}{$\begin{array}{l}\text { Ammonia Concentration } \\
(w t \%)\end{array}$} & 3.85 & 1.27 & 0.834 & 0.0841 & 0.0417 \\
\hline \multicolumn{2}{|c|}{$\begin{array}{l}\text { Ammonia Concentration } \\
\text { (molality) }\end{array}$} & $3.54 \mathrm{E}+00$ & $1.14 \mathrm{E}+00$ & 7.43E-01 & 7.43E-02 & $3.68 \mathrm{E}-02$ \\
\hline Temp. $\left({ }^{\circ} \mathrm{C}\right)$ & $\mathbf{K}_{\mathbf{H}}$ & \multicolumn{5}{|c|}{ Partial Pressure of Ammonia in Vapor Phase (atm) } \\
\hline 25 & 23.91 & $1.48 \mathrm{E}-01$ & 4.75E-02 & $3.11 \mathrm{E}-02$ & $3.11 \mathrm{E}-03$ & $1.54 \mathrm{E}-03$ \\
\hline 30 & 19.68 & $1.80 \mathrm{E}-01$ & 5.77E-02 & $3.78 \mathrm{E}-02$ & $3.78 \mathrm{E}-03$ & $1.87 \mathrm{E}-03$ \\
\hline
\end{tabular}
Salt Solution Containing Varying Amounts of Ammonia 


\begin{tabular}{|c|c|c|c|c|c|c|}
\hline & & & & & & \\
\hline 40 & 13.56 & $2.61 \mathrm{E}-01$ & $8.38 \mathrm{E}-02$ & $5.48 \mathrm{E}-02$ & $5.48 \mathrm{E}-03$ & $2.72 \mathrm{E}-03$ \\
\hline 50 & 9.55 & $3.70 \mathrm{E}-01$ & $1.19 \mathrm{E}-01$ & $7.78 \mathrm{E}-02$ & 7.78E-03 & $3.86 \mathrm{E}-03$ \\
\hline 56.96 & 7.68 & 4.61E-01 & $1.48 \mathrm{E}-01$ & $9.68 \mathrm{E}-02$ & $9.68 \mathrm{E}-03$ & 4.80E-03 \\
\hline 70 & 5.02 & 7.05E-01 & $2.26 \mathrm{E}-01$ & $1.48 \mathrm{E}-01$ & $1.48 \mathrm{E}-02$ & 7.34E-03 \\
\hline
\end{tabular}

Table 2. Calculated Partial Pressures of Ammonia in Equilibrium with 12.6 $\mathrm{M} \mathrm{Na}^{+}, 2.3 \mathrm{M} \mathrm{OH}^{-}$ Salt Solution Containing Varying Amounts of Ammonia

\begin{tabular}{|c|c|c|c|c|c|c|}
\hline & \multicolumn{6}{|c|}{ Liquid Phase Ammonia Concentrations } \\
\hline \multicolumn{2}{|c|}{$\begin{array}{l}\text { Ammonia Concentration } \\
(w t \%)\end{array}$} & 0.705 & 0.392 & 0.263 & 0.0263 & 0.0100 \\
\hline \multicolumn{2}{|c|}{$\begin{array}{l}\text { Ammonia Concentration } \\
\text { (molality) }\end{array}$} & $1.06 \mathrm{E}+00$ & 5.85E-01 & 3.91E-01 & $3.91 \mathrm{E}-02$ & $1.49 \mathrm{E}-02$ \\
\hline Temp. $\left({ }^{\circ} \mathbf{C}\right)$ & $\mathbf{K}_{\mathbf{H}}$ & \multicolumn{5}{|c|}{ Partial Pressure of Ammonia in Vapor Phase (atm) } \\
\hline 25 & 7.13 & $1.48 \mathrm{E}-01$ & $8.20 \mathrm{E}-02$ & 5.49E-02 & 5.49E-03 & $2.08 \mathrm{E}-03$ \\
\hline 30 & 6.28 & $1.68 \mathrm{E}-01$ & $9.31 \mathrm{E}-02$ & $6.23 \mathrm{E}-02$ & $6.23 \mathrm{E}-03$ & 2.37E-03 \\
\hline 40 & 4.94 & 2.14E-01 & $1.18 \mathrm{E}-01$ & 7.92E-02 & 7.92E-03 & $3.01 \mathrm{E}-03$ \\
\hline 50 & 3.95 & $2.67 \mathrm{E}-01$ & $1.48 \mathrm{E}-01$ & $9.90 \mathrm{E}-02$ & $9.90 \mathrm{E}-03$ & $3.76 \mathrm{E}-03$ \\
\hline 60 & 3.21 & $3.29 \mathrm{E}-01$ & $1.82 \mathrm{E}-01$ & $1.22 \mathrm{E}-01$ & $1.22 \mathrm{E}-02$ & $4.63 \mathrm{E}-03$ \\
\hline 70 & 2.64 & $3.99 \mathrm{E}-01$ & $2.21 \mathrm{E}-01$ & $1.48 \mathrm{E}-01$ & $1.48 \mathrm{E}-02$ & $5.62 \mathrm{E}-03$ \\
\hline
\end{tabular}

Figure 1. Calculated Partial Pressures of Ammonia in Equilibrium with 6.2 $\mathrm{M} \mathrm{Na}^{+}, 1.7 \mathrm{M} \mathrm{OH}^{-}$ Salt Solution Containing Varying Amounts of Ammonia 


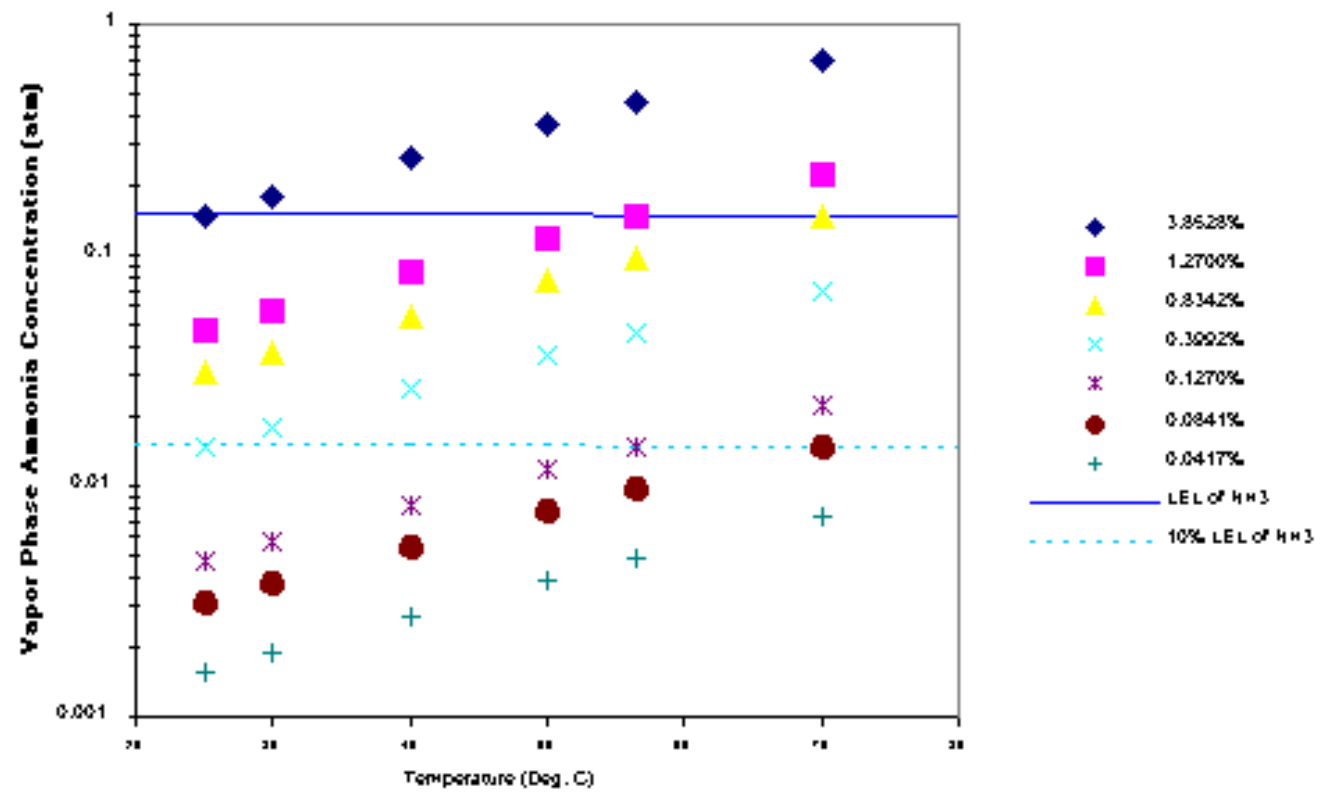

Figure 2. Calculated Partial Pressures of Ammonia in Equilibrium with $12.6 \mathrm{M}$ in $\mathrm{Na}^{+}$and $2.3 \mathrm{M}^{-}$ Salt Solution Containing Varying Amounts of Ammonia
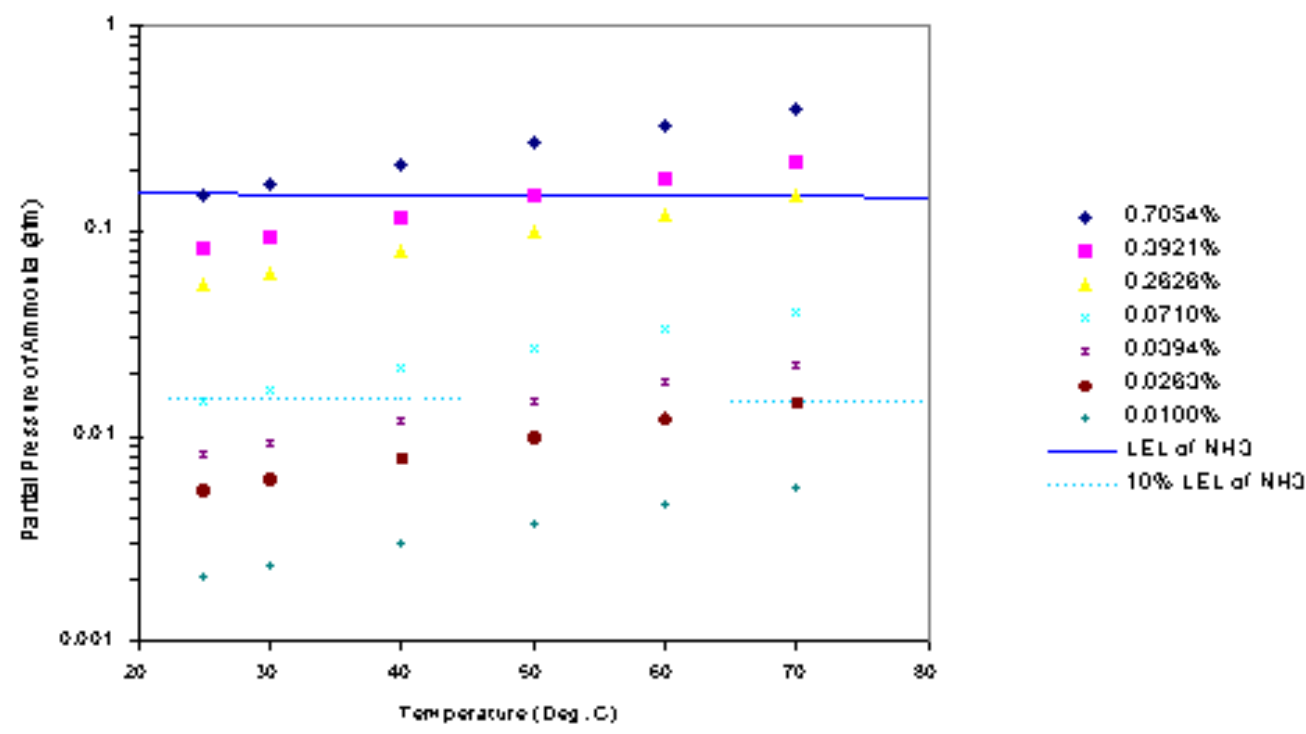

The corrected allowable ammonia concentration (10\% LFL) is $0.083 \mathrm{wt} \%$ in $6.2 \mathrm{M} \mathrm{Na}^{+}, 1.7 \mathrm{M} \mathrm{OH}^{-}$salt $^{2}$

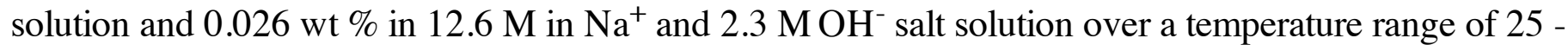
$70^{\circ} \mathrm{C}$. A flammable ammonia concentration cannot exist over a salt solution as long as the ammonia concentration is kept below these values. The WAC ${ }^{5}$ currently restricts the ammonia concentration to 0.127 wt $\%$, which is $10 \%$ of the ammonia concentration reported in Reference 1.

To maintain the equilibrium vapor phase ammonia concentration at $<=10 \%$ of the LFL (i.e., $1.48 \mathrm{vol} \%$ or $0.0148 \mathrm{~atm}$ ) over the temperature range of 25 to $70^{\circ} \mathrm{C}$, the liquid phase ammonia concentration must not exceed $0.084 \mathrm{wt} \%(1090 \mathrm{mg} / \mathrm{L}$ assuming a solution density of $1.3 \mathrm{~g} / \mathrm{mL})$. This concentration is about $35 \%$ 
lower that the current limit. Since virtually all of the salt solution that comes into the Tank Farm would have a concentration below $6.2 \mathrm{M} \mathrm{Na}^{+}, 1.7 \mathrm{M} \mathrm{OH}^{-}$it is conservative to use the ammonia concentration for that salt solution as the basis for the WAC. These sodium and hydroxide concentration restrictions should be placed on incoming transfers. However, if the Tank Farm accepts waste with a significantly higher salt concentration, a reduction in the allowable ammonia concentration to the values given for $12.6 \mathrm{M} \mathrm{Na}^{+}$and $2.3 \mathrm{M} \mathrm{OH}^{-}$should be considered. Note that the $10 \% \mathrm{LFL}$ limit is arbitrary and should not be considered immutable for all cases. If the need arises to receive material that has a higher concentration and analysis of the transfer indicates no problem then the transfer might be allowed with proper precautions.

\section{Siloxane Defoamer Usage}

In Reference 4, Jamison states the following about siloxane defoamers.

Siloxane defoamers are used to prevent or minimize foaming in the tank farm evaporators and DWPF Sludge Receipt Adjustment Tank (SRAT). The siloxane based defoamers are all relatively stable in highly radioactive fields, but begin to degrade after being exposed to high doses. After sufficient radiation, the defoamers form crosslinks and increase in viscosity. ${ }^{7}$ The defoamers also thermally degrade at very high temperatures or in a fire. Under a fire, the defoamer will degrade and form carbon oxides, traces of incompletely burned carbon compounds, silicon dioxide and formaldehyde. ${ }^{8}$ At temperatures of $150^{\circ} \mathrm{C}$ (under a vacuum in $\mathrm{KOH})$ the polydimethylsiloxane component forms cyclic volatile organic compounds. ${ }^{9}$

The vapor pressure for the cyclic volatile organic compounds is expected to be comparable to phenol. ${ }^{10}$ Phenol has a very low vapor pressure under tank farm storage conditions and would not significantly contribute to the composite lower flammability limit (CLFL). ${ }^{11}$ The other organic constituents that are also present in the defoamers are not expected to significantly contribute to the CLFL due the limited quantities and the significant dilution from tank farm supernatant.

\subsubsection{Required Controls to Safely Receive Defoaming Agents}

No controls are recommended for the defoaming agents that have been evaluated, since they are resistant to radiolytic, chemical and thermal degradation under the tank farm storage conditions. Additional studies are recommended to provide a stronger technical basis for the behavior of the defoamer under the tank farm storage conditions and long term process related impacts.

Polyorganosiloxanes are not considered a flammability hazard. Other than water, the main component in Dow Corning Antifoam H-10 Emulsion and Dow Corning Antifoam B Emulsion is polydimethylsiloxane (PDMS) at $\sim 10 \%$. Dow Corning 544 Antifoam compound contains 28\% PDMS and 38\% of a polydimethylsiloxane copolymer. The predominant reaction of the silicone polymers under highly alkaline aqueous conditions would be reversion (depolymerization). ${ }^{12,13,14}$, This would eventually lead to a mixture of silanolates ${ }^{15,16}$ (monomer, dimer, trimer, etc.) whose solubility in a high salt solution is likely to some degree but unknown. The silanolates would be the main product because of the high acidity of silanol. ${ }^{17,18}$ The silanolates are not volatile and do not pose a flammability hazard. Volatile and flammable cyclic oligosiloxanes could also form by way of intramolecular reaction, but with the high concentration of water and sodium hydroxide, the amount should be insignificant.

\section{References}


1. D. T. Hobbs, "Vapor Phase Ammonia Concentration in Equilibrium with Alkaline Salt Solutions," WSRC-TR-97-0062, February 27, 1997.

2. M. Layton, "Contribution of Organics to the Tank Farm Deflagrations", NI-HLW-98-007, May 7, 1998.

3. M. E. Jamison, "Implications of Organic Constituents and Ammonia on Tank Farm Flammability Controls (U)", WSRC-TR-98-00014, Revision 0, February 2, 1998.

4. M. E. Jamison, "Implications of Organic Constituents and Ammonia on Tank Farm Flammability Controls (U)", WSRC-TR-98-00014, Revision 1, April 27, 1998.

5. C. I. Aponte, "Waste Acceptance Criteria for High Level Waste Transfers to the 241-F/H Tank Farms (U)", X-SD-G-00001, Revision 3, December 1998.

6. J. D. Norton and L. R. Pederson, "Ammonia in Simulated Hanford Double-Shell Tank Wastes: Solubility and Effects on Surface Tension", PNL-10173, UC-600, September 1994.

7. Dow Corning Information on Radiation Stability for Silicones.

8. Material Safety Data Sheet, Dow Corning Corporation, Dow Corning ${ }^{\circledR} 544$ Antifoam Compound, February 7, 1995.

9. F. Rodriguez, Principles of Polymer Systems, $3^{\text {rd }}$ Edition, Hemisphere Publishing Corporation, 1989.

10. Personal Communication, R. Eibling to M. E. Jamison, January 1998.

11. M. J. Barnes, "Evaluation of the Flammability Potential of Transfers of DWPF Cold Chemical Run Recycle Stream Mercury-Bearing Waste (U)", WSRC-TR-95-0243, June 6, 1995.

12. Fleming, "Organic Silicon Chemistry" in Comprehensive Organic Chemistry, Chapter 13, Volume 2, Pergamon Press, 1979.

13. M. G. Voronkov, V. P. Mileshkevich, and Y. A. Yuzhelevskii, The Siloxane Bond, Plenum Press, New York, 1978.

14. W. Noll, Chemistry and Technology of Silicones, Academic Press, New York, 1968.

15. M. Cypryk, S. Rubinsztajn, and J. Chojnowski, Journal of Organometallic Chemistry, Vol. 91, p. 446, 1993.

16. S. Rubinsztajn, M. Cypryk, and J. Chojnowski, Macromolecules, Vol. 26, p. 5389, 1993.

17. R. Reals, Encyclopedia of Chemical Technology, $2^{\text {nd }}$ Edition, Vol 18, pp. 221-260, 1969.

18. Z. Lasocki and S. Chrzczonowicz, Journal of Polymer Science, Vol. 59, p. 259, 1962. 